\title{
Disinfection by-products in drinking water distribution system of Bucharest City
}

\author{
IULIANA PAUN, FLORENTINA LAURA CHIRIAC*, VASILE ION IANCU, FLORINELA \\ PIRVU, MARCELA NICULESCU, NICOLETA VASILACHE
}

National Research and Development Institute for Industrial Ecology ECOIND, 57-73 Drumul Podu Dambovitei Street, district 6, 060652, Bucharest, Romania

*Corresponding author: laura.chiriac@incdecoind.ro

$\begin{array}{lll}\text { Received: } & \text { Accepted: } & \text { Published: } \\ \text { 24.02.2021 } & 15.03 .2021 & 25.06 .2021\end{array}$

\begin{abstract}
Chlorine is widely used in Romania and all over the world as disinfectant of drinking water. During chlorination process the natural organic matter and inorganic ions react with chlorine forming disinfection by-products (DBPs). The predominant organic disinfection by-products are trihalomethanes (THMs) while the main inorganic disinfection by-products are chlorate and chlorite ions. THMs were detected in all investigated drinking water samples from Bucharest distribution system with values from $27.8 \mu \mathrm{g} / \mathrm{L}$ up to $75.1 \mu \mathrm{g} / \mathrm{L}$, which are below the maximum concentration value admitted by Romanian drinking water legislation of $100 \mu \mathrm{g} / \mathrm{L}$. Chloroform constitutes the major component in total THMs concentration found in all tested drinking water. Chlorate and chlorite anions were not detected in any of the investigated drinking water samples. THMs concentration was correlated with total organic carbon (TOC), residual chlorine and chloride.
\end{abstract}

Keywords: disinfection by-products, chlorine, trihalomethanes, drinking water distribution system

\section{INTRODUCTION}

Disinfection is the most important process for removal microorganism from drinking water [1]. In Romania, surface water is the main source of drinking water (approximately 40\%) [2, 3]. Raw water, especially surface waters, which are rich in natural organic matter and inorganic ions, react with chemical disinfectants forming new chemicals species, water disinfection by-products (DBPs) [4].

The common disinfectants are chlorine, chlorine dioxide, ozone and chloramine. Ozone can only be used as a primary disinfectant and chloramines can be used as secondary disinfectants, while chlorine and chlorine dioxide can serve as primary or secondary disinfectants.

Chlorination is the most used technological step of drinking water treatment to prevent the proliferation of microorganisms, being extremely efficient and cost effective. The use of chlorine can be a health hazard due to the formation of carcinogenic halo-organic compounds as disinfection by-products such as trihalomethanes (THMs) [5]. As such, the formation of THMs during chlorination process is important and need to be monitored. The presence of trihalomethanes in drinking water is influenced by $\mathrm{pH}$, total organic carbon (TOC) (natural organic matter, humic and fulvic acid), dose of chlorine, turbidity and ammonium concentration of raw water [6]. However, chlorinated drinking water may also contain other DBPs classes: haloacetic acids, halonitromethanes, haloacetonitriles, chloramines, chlorophenols, the so-called mutagen $\mathrm{X}$, bromate and chloral hydrate. The chlorine dioxide generates in drinking water inorganic DBPs such as chlorite, chlorate and chloride. Disinfection with chlorine dioxide does not form THMs. The use of ozone as a disinfectant for drinking water can lead to the formation the bromate, formaldehyde, 
other aldehydes, peroxides and brominated methane. In drinking water disinfected with chloramine can be identified dichloramines, trichloramines, cyanogen chloride and chloral hydrate [7].

The bactericidal efficiency of disinfectants increases in order $\mathrm{O}_{3}<\mathrm{Cl}_{2}<\mathrm{ClO}_{2}<$ chloramines, while their stability in water is reversed [8]. The potential health effects from long-term exposure of disinfection compounds and some of their disinfection by products are presented in Table 1 [9].

Table 1. Potential health effects from long-term exposure of disinfection compounds and disinfection by-products

\begin{tabular}{l|l}
\hline Disinfection compound & Potential health effects from long term exposure \\
\hline Chloramines & Eye/nose irritation; stomach discomfort, anemia \\
Chlorine & Eye/nose irritation; stomach discomfort \\
Chlorine dioxide & Anemia; infants and young children: nervous system effects \\
\hline DBPs /compound & Potential health effects from long term exposure \\
\hline Bromate & Increased risk of cancer \\
Chlorite & Anemia; infants and young children: nervous system effects \\
Total Trihalomethanes & Liver, kidney or central nervous system problems; increased \\
(TTHMs) & risk of cancer \\
\hline
\end{tabular}

DBPs have been linked to liver, kidney, and large intestine cancer, as well as reproductive and developmental issues [10,11].

The drinking water international legislation regulate a very large number of disinfection byproducts, both inorganic (bromate, chlorate and chlorite) and organic (trihalomethanes, formaldehyde, chloro-phenols, dichlorophenols, etc.) compounds. DBPs concentration levels reported by different countries are presented in Table 2 .

Table 2. Legislation and guidelines for DBPs

\begin{tabular}{|c|c|c|c|c|c|c|c|c|}
\hline DBPs & $\begin{array}{l}\text { Chinese } \\
\text { standards }\end{array}$ & $\begin{array}{l}\text { WHO } \\
\text { guidelines }\end{array}$ & $\begin{array}{l}\text { USA } \\
\text { regulations }\end{array}$ & $\begin{array}{l}\text { Canadian } \\
\text { guidelines }\end{array}$ & $\begin{array}{l}\mathrm{EU} \\
\text { directive }\end{array}$ & $\begin{array}{l}\text { Japanese } \\
\text { standards }\end{array}$ & $\begin{array}{l}\text { Australian } \\
\text { guidelines }\end{array}$ & $\begin{array}{l}\text { Romanian } \\
\text { regulations }\end{array}$ \\
\hline Bromate (mg/L) & 0.01 & 0.01 & 0.01 & 0.01 & 0.01 & 0.01 & 0.02 & 0.01 \\
\hline Chlorite (mg/L) & 0.7 & 0.7 & 1 & 1 & - & - & 0.8 & - \\
\hline Chlorate (mg/L) & 0.7 & 0.7 & - & 1 & - & - & - & - \\
\hline THMs $(\mu \mathrm{g} / \mathrm{L})$ & 100 & - & 80 & 100 & 100 & 100 & 250 & 100 \\
\hline -chloroform & & 200 & & & & & & \\
\hline - bromoform & & 100 & & & & & & \\
\hline -bromodichloromethane & & 60 & & & & & & \\
\hline -dibromochloromethane & & 100 & & & & & & \\
\hline
\end{tabular}

Coagulation, anion exchange, membrane, activated carbon and ozone are technical solutions regularly implemented WWTPs scale for minimize the organic and inorganic precursors formation, which are responsible for the disinfection by products formation [12].

The aim of this study was to investigate the DBPs (chlorate, chlorite and trihalomethanes) concentration level in drinking water from Bucharest distribution system.

\section{MATERIALS AND METHODS}

Sample collection

The source of drinking water in Bucharest comes from the surface water (Arges and Dambovita rivers). Chlorine is used as disinfectant for drinking water in Bucharest water treatment plants. Drinking water samples were collected from 25 end user sampling points, which are part of the Bucharest distribution system. All of the water samples were collected according to standard 
method ISO 5667-5:2017 [13]. Sampling was performed from the tap, after the drinking water was allowed to flow for at least 3 minutes, at maximum flow. After collection, the drinking water samples were stored in an icebox and transported to laboratory for analysis. Sample preparation involved the filtration of each sample through a $0.45 \mu \mathrm{m}$ filter syringe before chloride, bromide, chlorate and chlorite analysis.

\section{Sample analysis}

During the present study, drinking water samples were analyzed for the following parameters: $\mathrm{pH}$, conductivity, turbidity, total organic carbon, chloride, bromide, free chlorine, total chlorine, four THMs (chloroform, bromodichloromethane, dibromochloromethane and tribromomethane), chlorate and chlorite anions.

\section{Instruments and analytical methods}

PH and conductivity were measured using a multiparameter (WTW Multi 9620 ISD, Germany), whereas turbidity parameter was analyzed with a turbidimeter (WTW 555-IR, Germany). Free and total chlorine indicators were determined according to SR EN ISO 7393-2:2018 (method with N,Ndiethyl-1,4-phenylenediamine (DPD)) using a spectrophotometer (UV-VIS Lambda 25 Perkin Elmer, United States). Total organic carbon was measured using a total organic carbon analyzer, (TOC/TN-LCPN, Shimadzu, Japan) according to SR EN 1484:2001.

Levels of trihalomethanes (chloroform, bromodichloromethane, dibromochloromethane and tribromo-methane) in drinking water were measured using an Agilent 6890B GC coupled to an Agilent 7010B triple quadrupole MS detector (Agilent Technologies, United States) by headspace GC-MS technique, according to ISO 20595:2018 (E).

Anions (chloride, bromide, chlorate and chlorite) were determined by ion chromatograph DIONEX ICS5000 coupled with a suppressed conductivity detector (ASRS-4m as conductivity suppressor) using a method developed in the laboratory. The IC chromatographic operating parameters are presented in Table 3.

Table 3. Ion-chromatography operating parameters for anions determination (chlorite, bromide, chlorate and chloride)

\section{Chromatographic parameters Description}

\section{IC column}

Eluent composition

Flo rate of eluent

Sample injection volume

Temperature

Detector

Run time
AS19-HC analytical column (250 mm x 4 mm I.D.), AG19HC guard column (50 mm x 4 mm I.D.)

Potassium hydroxide $25 \mathrm{mmol} / \mathrm{L}$

$1 \mathrm{~mL} / \mathrm{min}$

$350 \mu \mathrm{L}$

$30^{\circ} \mathrm{C}$

Suppressed conductivity, $25 \mathrm{~mA}$ current

$20 \mathrm{~min}$

\section{RESULTS AND DISCUSSION}

\section{Characteristics of drinking water samples}

Chemical parameters of drinking water samples are summarized in Table 4. The values determined for $\mathrm{pH}$ and conductivity in the analyzed drinking water were situated in a rather narrow range, namely between 7.1 and 7.6 for $\mathrm{pH}$ and between 298 and $316 \mu \mathrm{S} / \mathrm{cm}$ for conductivity. The values determined for turbidity ranged between $0.08-0.54 \mathrm{NTU}$, being almost ten times lower than the maximum acceptable value, which is 5 NTU.

The bromine concentration was found to be less than the limit of quantification of the method, while the chloride concentration levels were relatively low $(9.2$ to $24.8 \mathrm{mg} / \mathrm{l})$ for all analyzed water 
samples. Another parameter monitored for drinking water samples was DOC. The determined values did not show any abnormal changes, these being situated between 1.33 and $4.16 \mathrm{mg} / \mathrm{L}$.

The concentration of free chlorine and total chlorine was determined in all drinking water samples and the obtained values were lower than $0.5 \mathrm{mg} / \mathrm{L}$.

Table 4. Physical and chemical parameters determined in drinking water samples

\begin{tabular}{lccccc}
\hline Parameter & Minimum & Maximum & Median & Mean & Acceptable value [14] \\
\hline $\mathrm{pH}$ & 7.10 & 7.6 & 7.5 & 7.4 & $6.5-8.5$ \\
Conductivity $(\mu \mathrm{S} / \mathrm{cm})$ & 298 & 316 & 310 & 307 & 2500 \\
Turbidity $(\mathrm{NTU})$ & 0.08 & 0.54 & 0.21 & 0.25 & 5 \\
Chloride $(\mathrm{mg} / \mathrm{L})$ & 9.2 & 24.8 & 18.8 & 18.3 & 250 \\
Free chlorine $(\mathrm{mg} / \mathrm{L})$ & 0.14 & 0.50 & 0.33 & 0.33 & $1-5$ \\
Total chlorine $(\mathrm{mg} / \mathrm{L})$ & 0.19 & 0.50 & 0.40 & 0.38 & - \\
TOC $(\mathrm{mg} / \mathrm{L})$ & 1.33 & 4.16 & 1.59 & 1.7 & - \\
\hline
\end{tabular}

\section{Concentration of DBPs}

The concentration of chlorate and chlorite ions were lower than method LOQ values for all investigated samples. The lack of these degradation by-products in the analyzed drinking water samples represents an important drinking water quality indicator, considering that high values of chlorite and chlorate in drinking water can present a major risk for people health. It has been shown that women exposed to concentrations higher than $700 \mu \mathrm{g} / \mathrm{L}$ can give birth to children with kidney failure, abdominal wall defect and cleft palate, while women exposed to concentrations between 200 and $700 \mu \mathrm{g} / \mathrm{L}$ can give birth to newborns with obstructive urinary defects, cleft palate and spina bifida [15].

Four THMs were detected in all of the drinking water samples. Table 5 shows the minimum, maximum, median and mean concentration of trihalomethanes levels. Chloroform $(\mathrm{CHCl} 3)$, dichlorobromo-methane $(\mathrm{CHCl} 2 \mathrm{Br})$, dibromochloromethane $(\mathrm{CHBr} 2 \mathrm{Cl})$ and bromoform $(\mathrm{CHBr} 3)$ could be quantified in all these samples. Similar to other studies reported in the literature, chloroform was the major degradation product obtained in chlorinated drinking water [16], figure 1.

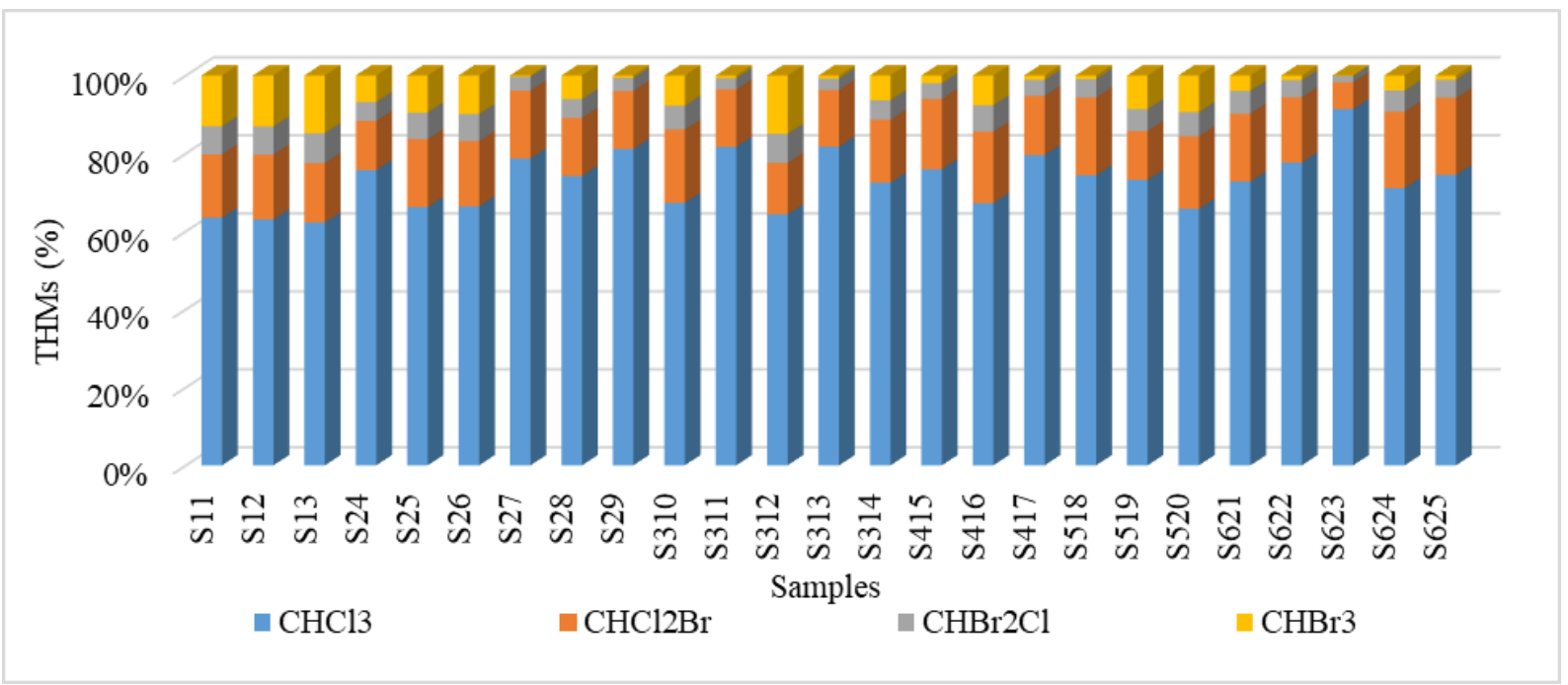

Fig. 1. Percentage fraction of chloroform, bromodichloromethane, dibromochloromethane and bromoform related to total THMs content

The chloroform concentration values ranged between $28.7 \mu \mathrm{g} / \mathrm{L}$ and $68.6 \mu \mathrm{g} / \mathrm{L}$, representing $62.29 \%-91.35 \%$ of the total THM amount. The mean value of chloroform was $30.8 \mu \mathrm{g} / \mathrm{L}$, while the standard deviation was $9.74 \mu \mathrm{g} / \mathrm{L}$. The higher concentration values of chloroform determined in 
drinking water may be due to the higher levels of organic matter in raw water. The concentration values of bromodichloromethane $\left(\mathrm{CHCl}_{2} \mathrm{Br}\right)$ was situated between 5.0 and $8.5 \mu \mathrm{g} / \mathrm{L}$, the contribution of bromodichloromethane was between $6.89-19.96 \%$ of the total amount of THMs.

Table 5. Mean values of THMs concentration in drinking water samples from Bucharest distribution system

\begin{tabular}{lccccc}
\hline Statistical parameters & $\mathbf{C H C l}_{\mathbf{3}}$ & $\mathbf{C H C l}_{2} \mathbf{B r}$ & $\mathbf{C H B r}_{2} \mathbf{C l}$ & $\mathbf{C H B r}_{\mathbf{3}}$ & THMs \\
\hline Min $(\mu \mathrm{g} / \mathrm{L})$ & 20.7 & 5.0 & 1.1 & 0.1 & 27.8 \\
Max $(\mu \mathrm{g} / \mathrm{L})$ & 68.6 & 8.5 & 3.5 & 6.4 & 75.1 \\
Median $(\mu \mathrm{g} / \mathrm{L})$ & 27.4 & 6.6 & 2.1 & 2.6 & 41.1 \\
Mean $(\mu \mathrm{g} / \mathrm{L})$ & 30.8 & 6.5 & 2.1 & 2.4 & 42.0 \\
SD $(\mu \mathrm{g} / \mathrm{L})$ & 9.74 & 0.94 & 0.73 & 2.15 & 9.87 \\
$\%$ of THMs & & & & & \\
Min & 62.29 & 6.89 & 1.66 & 0.09 & - \\
Max & 91.35 & 19.96 & 7.68 & 14.97 & \\
\hline
\end{tabular}

The concentration of dibromochloromethane $(\mathrm{CHClBr} 2)$ was found between $1.1-3.5 \mu \mathrm{g} / \mathrm{L}$, whereas the concentration of bromoform $(\mathrm{CHBr} 3)$ was detected in the range of $0.1-6.4 \mu \mathrm{g} / \mathrm{L}$. The dibromochloromethane and bromoform contributed with $1.66-7.68 \%$ and $0.09-14.97 \%$, respectively, to total trihalomethane value. The mean and median dibromochloromethane and bromoform concentrations were very close values, meaning 2.1 and 2.6 respectively.

The average concentrations of trihalomethanes followed the order chloroform > bromodichloromethane $>$ bromoform $>$ dibromochloromethane. Similar observations had been reported also in literature (Table 6). When raw water contains bromide it can form bromodichloromethane, dibromochloromethane and bromoform in chlorinated drinking water [17]. In all the investigated drinking water samples the concentration of total THMs did not exceed the maximum concentration value admitted by Romanian drinking water legislation which is $100 \mu \mathrm{g} / \mathrm{L}$.

Table 6. DBP level reported in several studies in water distribution systems from different countries

\begin{tabular}{|c|c|c|c|c|c|c|}
\hline Disinfectant used & $\begin{array}{l}\mathrm{CHCl}_{3} \\
(\mu \mathrm{g} / \mathrm{L})\end{array}$ & $\begin{array}{c}\mathrm{CHCl}_{2} \mathrm{Br} \\
(\mu \mathrm{g} / \mathrm{L})\end{array}$ & $\begin{array}{c}\mathrm{CHBr}_{2} \mathrm{Cl} \\
(\mu \mathrm{g} / \mathrm{L})\end{array}$ & $\begin{array}{c}\text { CHBr3 } \\
(\mu \mathrm{g} / \mathrm{L})\end{array}$ & $\begin{array}{l}\text { THMs } \\
(\mu \mathrm{g} / \mathrm{L})\end{array}$ & City, Country \\
\hline Chlorine & $5.9-29.1$ & $2.7-6.4$ & $0.2-3.1$ & $0.05-0.2$ & - & Athens, Greece [18] \\
\hline Chlorine & ND-43.5 & $1.3-29.1$ & $3.5-18.5$ & $0.5-8.8$ & $11.1-88.6$ & France [19] \\
\hline $\begin{array}{l}\text { Chlorine } \\
\text { Chloramine }\end{array}$ & - & - & - & - & $\begin{array}{c}124-419 \\
23-160\end{array}$ & Scotland, UK [20] \\
\hline Chlorine dioxide & $0-5.0$ & $0-26.0$ & $0-73.0$ & $1-73$ & - & Qatar [21] \\
\hline Chlorine & - & - & - & - & $\begin{array}{l}\mathrm{ND}- \\
133.2\end{array}$ & Taiwan [22] \\
\hline Chlorine & $\begin{array}{l}1.13- \\
212.2\end{array}$ & $0.02-228.9$ & $0-99.3$ & 24.01 & $1.41-574.2$ & Ardabil, Iran [23] \\
\hline Chlorine & $\begin{array}{c}20-317 \\
139-363\end{array}$ & $\begin{array}{c}0.3-9.0 \\
\text { ND }-9.0\end{array}$ & $\begin{array}{c}2.5-13.8 \\
0.3-4.6\end{array}$ & - & - & $\begin{array}{l}\text { Rawalpindi and } \\
\text { Islamabad, Pakistan [24] }\end{array}$ \\
\hline Chlorine & $26.9-27.6$ & $4.5-4.7$ & $17.2-18.0$ & $\begin{array}{l}36.7- \\
37.3\end{array}$ & $85.6-97.4$ & Timisoara, Romania [25] \\
\hline Chlorine & $1.4-10.7$ & $1.0-5.8$ & $0.8-3.6$ & ND-1.2 & - & Toronto, Canada [26] \\
\hline Chlorine & $1.2-6.1$ & $0.5-3.4$ & ND-1.2 & ND-0.7 & - & Dhahran, Saudi Arabia [26] \\
\hline Chlorine & $0.9-89.2$ & ND-25.2 & ND-13.2 & ND-0.7 & - & 35 major cities, China [27] \\
\hline Chlorine & - & - & - & - & $231-484$ & India [28] \\
\hline Chlorine & - & - & - & - & $269-594$ & India [29] \\
\hline Chlorine & - & - & - & - & $274-511$ & India [30] \\
\hline
\end{tabular}

ND: below the detection limit

Correlation between THMs, free chlorine, TOC and chloride 
Residual chlorine is an important parameter because its variability affects the quality of water within the distribution system. Pearson correlation tests were performed to determine the relationship among THMs, free chlorine, TOC and chloride results, where $p$ value $<0.05$ means significant positive relationships.

Thus, it was established that no correlations could be made between any of the free chlorine and chlorides concentration and THMs formation, in none of the analyzed samples (figures $2 \mathrm{a}$ and $2 \mathrm{~b}$ ). Pearson values were -0.108 ( $\mathrm{p}$ value $=0.608$ ) for the data set free chlorine and THMs levels and 0.148 ( $\mathrm{p}$ value $=0.504)$ when the chloride levels were compared with THMs formation. These values, very close to 0 indicates no evidence of any relationship between the two data sets.

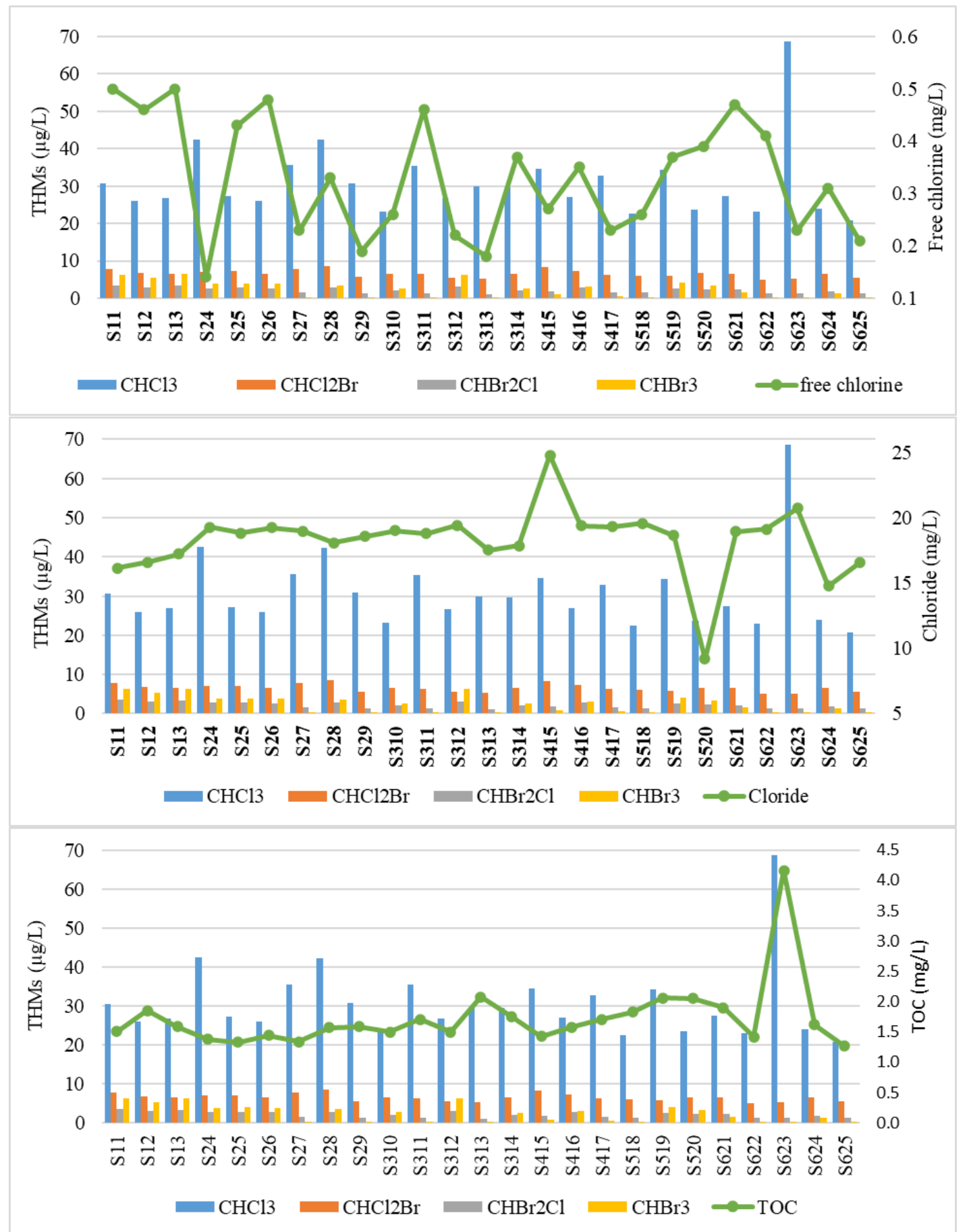

a)

b)

c)

Fig. 2. Variation of THMs concentration with free chlorine (a), chloride (b) and TOC (c) content 
Calculating the Pearson's correlation between TOC concentration and THMs level, a strong positive correlation was observed. The value of the Pearson coefficient was, in this case, 0.606 with $\mathrm{p}$ value of 0.002 . The $\mathrm{p}$ value, lower than the significance level of 0.05 , suggests that the results are statistically significant, which means that there is a close relationship between the two data sets. However, this correlation can also be seen in figure 2c, where highest concentration of chloroform $(68.6 \mu \mathrm{g} / \mathrm{L})$ corresponds to the highest concentration of TOC $(4.16 \mathrm{mg} \mathrm{C} / \mathrm{L})$, which means that a high amount of the TOC concentration is due to the chloroform content.

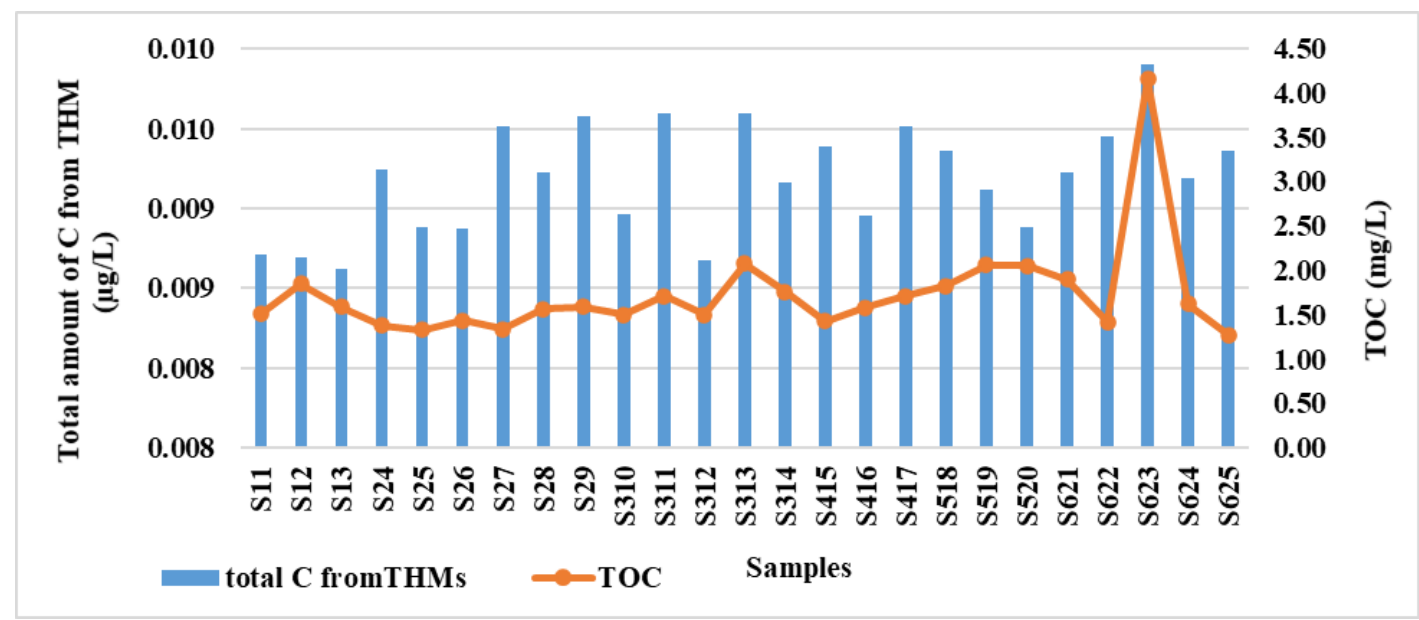

Fig. 3. Variation of carbon in THMs in relation to the total carbon content

However, from the graphic representation of the total carbon concentration from the trihalomethane content and the TOC concentration (Figure 3), it can be seen that the organic matter content is not only due to the presence of trihalomethanes in the analyzed samples, but they may also contain other organic compounds that are not subject of this study. In all cases, TOC values were much higher than those for the total carbon amount calculated from the THMs content. Pearson's correlation value was 0.407 ( $\mathrm{p}$ value $=0.044$ ). The value of $\mathrm{p}$, very close to the significance level of 0.05 , indicates a correlation, may indicate a weak correlation between the two indicators.

Calculating the chlorine content of THMs and comparing the resulting values with the chlorine concentrations determined by ion chromatography, it can be seen that no correlations can be made between the two sets of values (figure 4).

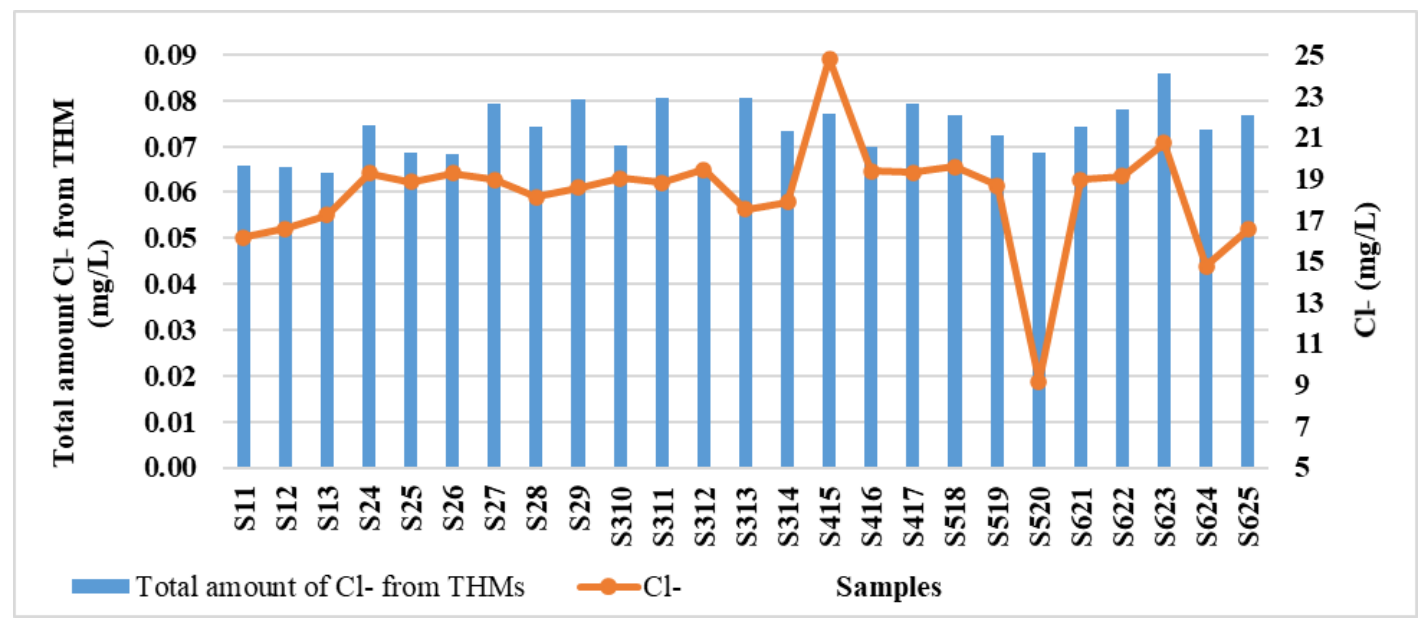

Fig. 4. Variation of the chloride amount from THMs in relation to the total chloride content

This observation is also supported by the Pearson correlation coefficient, whose value is 0.351 with a value of 0.087 , indicating that there is no correlation between the two sets of values. Although 
following a similar trend, the chlorine content of THMs is much lower than the concentration levels determined as such in water samples. In this case, the chloride content may come from the presence in drinking water of both inorganic compounds, such as various chlorinated salts, and organic ones, which were not targeted in this study. In either case, further investigation is required.

\section{CONCLUSIONS}

The application of chlorine as a disinfection agent in water treatment plants favors the production of disinfection by-product (chlorate, chlorite and trihalomethanes). Inorganic by-products were not detected in any of the investigated drinking water samples, while the concentration of total trihalomethane did not exceed the maximum permissible value of Romanian drinking water legislation of $100 \mu \mathrm{g} / \mathrm{L}$. Chloroform represented the major component in total trihalomethanes in all the analyzed samples. Considering TOC content, it was found that only $0.71 \%$ represents the carbon from THMs, while of the total chlorides only $0.75 \%$ represents the chloride ion in THMs. In both cases, although determined at fairly high concentration levels, the trihalomethane content does not have a major contribution to TOC and chlorine concentration, respectively. The average concentrations of THMs followed the order chloroform $>$ bromodichloromethane $>$ bromoform $>$ dibromochloromethane. The chloroform, bromodichloromethane, bromoform and dibromochloromethane were detected in drinking water samples in concentration levels ranged from $28.7 \mu \mathrm{g} / \mathrm{L}-68.6 \mu \mathrm{g} / \mathrm{L}, 5.0 \mu \mathrm{g} / \mathrm{L}-8.5 \mu \mathrm{g} / \mathrm{L}, 0.1 \mu \mathrm{g} / \mathrm{L}-6.4 \mu \mathrm{g} / \mathrm{L}$ and $1.1 \mu \mathrm{g} / \mathrm{L}-3.5 \mu \mathrm{g} / \mathrm{L}$, respectively. The order of THM compounds could be influenced by the presence of bromide ions in the raw water.

\section{ACKNOWLEDGEMENTS}

The authors acknowledge the financial support offered by National Research Program "Nucleu" through contract number 20N/2019, Project code PN 19040101.

\section{REFERENCES}

[1] BANCIU, A.R., IONESCU, L., IONICA, D.L., MITRU, D., NITA-LAZAR, M., Rev. Chim., 71, no. 1, 2020, p. 57.

[2] PATROESCU, V., JINESCU, C., COSMA, C., CRISTEA, I., BADESCU, V., STEFAN, C.S., Rev. Chim., 66, no.4, 2015, p. 537.

[3] PAUN, I., CHIRIAC, F.L., MARIN, N.M., CRUCERU, L.V., PASCU, L.F., LEHR, C.B., ENE, C., Rev. Chim., 68, no. 8, 2017, p. 1732.

[4] CORTES, C., MARCOS, R., Mutat. Res. Genet. Toxicol. Environ. Mutagen., 831, 2018, p. 1.

[5] PAUZI ABDULlAH, MD., YEW, C.H., BIN RAMLI, M.S., Water Res., 37, no. 19, 2003, p. 4637.

[6] GALLARD, H., VON GUNTEN, U., Water Res., 36, no.1, 2002, p. 65.

[7] STEFAN, D., ERDELYI, N., IZSAK, B., ZARA, Y.G., VARGHA, M., Microchem. J., 149, 2019, 104004, https://doi.org/10.1016/j.microc.2019.104004.

[8] HOFF, J.C., GELDREICH, E.E., J. Am. Water Works Ass., 71, no. 1, 1981, p. 40.

[9] National Primary Drinking Water Regulations, EPA 816-F-09-004, may 2009.

[10] BOORMAN, G.A., DELlARCO, V., DUNNICK, J.K., CHAPIN, R.E., HUNTER, S., HAUCHMAN, F., GARDNER, H., COX, M., SILLS, R.C., Environ. Health Perspect., 107, 1999, p. 207.

[11] LIU, S.G., ZHU, Z.L, FAN, C.F., QIU, Y.L., ZHAO, J.F., J. Environ. Sci., 23, no. 9, 2011, p. 1503.

[12] BOANO, F., FIORE, S., REVELLI, R., $16^{\text {th }}$ Conference on Water Distribution System Analysis, WDSA 2014, Procedia Engineering 89, 2014, p. 255.

[13] ISO 5667-5:2006 Water quality -Sampling-Part 5: Guidance on sampling of drinking water from treatment works and piped distribution systems, Available from: https://www.iso.org/standard/36694.html [05.02.2021]. 
[14] LAW 458/2002 on drinking water quality, http://legislatie.just.ro/Public/DetaliiDocument/37723 [11.01.2021]

[15] RIGHI, E., BECHTOLD, P., TORTORICI, D., LAURIOLA, P., CALZOLARI, E., ASTOLFI, G., NIEUWENHUIJSEN, M., FANTUZZI, G., AGGAZZOTTI, G., Environ. Res., 116, 2002, p. 66.

[16] THOKCHOM, B., RADHAPYARI, K., DUTTA, S., Disinfection By-products in Drinking Water, 2020, p. 83, https://doi.org/10.1016/B978-0-08-102977-0.00004-4.

[17] RICHARDSON, S., PLEWA, M., WAGNER, E., SCHOENY, R., \& DEMARINI, D., Mutat. Res.-Rev. Mutat. Res., 636, 1-3, 2007, p. 178.

[18]. GOLFINOPOULOS, S.K., NIKOLAOU, A.D, LEKKAS, T.D., Environ. Sci. Pollut. Res., 10, no. 6, 2003, p. 368.

[19] MOULY, D., JOULIN, E., ROSIN, C., BEAUDEAU, P., ZEGHNOUN, A., OLSZEWSKIORTAR, A., MUNOZ, J.F., WELTER, B., JOYEUX, M., SEUX, R., MONTIEL, A., RODRIGUEZ, M.J., Water Res., 44, 2010, p. 5168.

[20] GOSLAN, E.H., KRASNER, S.W., BOWER, M., ROCKS, S.A., HOLMES, P., LEVY, L.S., PARSONS, S., Water Res., 43, 2009, p. 4698.

[21] Alotoum, F., AlghOUTI, M.A., AHMED, T.A., ABU-DIEYEH, M., ALI, M., Chemosphere, 164, 2016, p. 649.

[22] CHANG, H.H., TUNG, H.H., CHAO, C.C., WANG, G.S., Environ. Monit. Assess. 162, 2010, p. 237.

[23] SADEGHI, H., NASSERI, S., YUNESIAN, M., J. Environ. Health. Sci. Engineer., 17, 2019, p. 619.

[24] AMJAD, H., HASHMI, I., SAIF UR REHMAN, M., AWAN, M.A., GHAFFAR, S., KHAN, Z., Ecotoxicol. Environ. Saf, 91, 2013, p. 25.

[25] COSMA, C., NICOLAU, M., PATROESCU, V., STEFANESCU, M., BALlO, A., FLORESCU, S., J. Environ. Prot. Ecol, 10, no. 1, 2009, p. 14.

[26] CHOWDHURY, S., Sci. Total Environ., 463-464, 2013, p. 922.

[27] PAN, S., AN, W., LI, H., SU, M., ZHANB, J., YANG, M., J. Hazard. Mater., 280, 2014, p. 288.

[28] KUMARI, M., GUPTA, S.K., Environ. Sci. Pollution Res. 22, no.16, 2015, p. 12615.

[29] MISHRA, B.K., GUPTA, S.K., SINHA, A., J. Environ. Health Sci. Eng., 12, no.1, 2014, p. 73.

[30] KUMARI, M., GUPTA, S.K., MISHRA, B.K., Ecotoxicol. Environ. Saf., 113, 2015, p. 433.

Citation: Paun, I., Chiriac, F.L., Iancu, V.I., Pirvu, F., Niculescu, M., Vasilache, N., Disinfection by-products in drinking water distribution system of Bucharest City, Rom. J. Ecol. Environ. Chem., 2021, 3, no. 1, pp. 10-18.

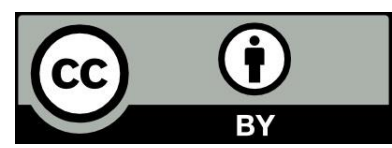

(C) 2021 by the authors. This article is an open access article distributed under the terms and conditions of the Creative Commons Attribution (CC BY) license (http://creativecommons.Org/licenses/by/4.0/). 